XIV. Relation of the Lord Fanconberg's Embassy to the States of Italy in the year 1669, addressed to King Charles II.; transcribed from the original MS. signed by Lord Fauconberg himself, preserved in a Volume of the Sloane Collection in the British Museum, No. 2752. Communicated by Sir HENRY ELIIS, K.H. F.R.S. Director.

Read 5th and 19th March, 1857.

\footnotetext{
*** Granger, in the Third Volume of his Biographical History of England, gives the following account of Lord Fauconberg:-

"Thomas Bellasyse, Viscount Falconberg, was one of the Council of State to Cromwell, whose daughter Mary he married. He was much in favour with Charles II., and was sent ambassador by him to the State of Venice, and the Princes of Italy. In 1672 he succeeded his uncle John, Lord Bellasyse, as Captain of the band of pensioners, and was created Earl of Falconberg by King William, April 9, 1689. He died December 31, 1700."
}

May it please your most Excellent Majesty.

WARRANTED as well by the generall practice of Ambassadors of the late and present age as commanded by your Majesty's instructions of the 10th of January, in the 21 yeare of your Majesty's most happy raigne, at such time as you were graciously pleased to honor me with the caracter of your Extraordinary Ambassador to divers of the Princes of Italy, I most humbly prostrate at your Majesty's feet, and doe with all submission and reverence offer to your Majesty's consideration this following accompt of the Observations I made in the several places where I carryed that caracter.

I left London on Tuesday the 18th of January, 166 $\frac{9}{70}$, towards Dover. At my arrival at Calais the French king, pre-informed I suppose of my caracter, had given order I should bee received with all honor and respect due to one who was employed by your most excellent Majesty. The governor and civile magistrates of the town visited me. The officers of the custome house brought me an order, under the king's hand, commanding them to let passe my baggage trayne and servants, coaches, and 62 horses, without searching into the one or paying for the other. I was treated with the same respect and honor in all the citties and garrisons by which I passed until I arrived at Paris, where I understood Madame was retired to Villars Costeretz with Monsieur, who had conceived some disgust at the disgrace then lately befaln the Chevalier de Loraine. I omitted not to 
waite upon her Highnesse in her said retyrement as my duty obliged me, and, encouraged as well by her as convinced by the reasonableness of the thing, I went to St. Germain's to wait upon that King, who received me with all imaginable kindness. I was treated with much respect in that court, to which I was not altogether a stranger.

I forbeare to say more of that Prince or Court, the interest of that crown and government your Majesty is not uninformed of; besides, it is the province of another of your Majesty's servants who has resided much longer there, and doubt. lesse is better able to informe your Majesty minutely of these things then I can reasonably be supposed to doe.

I doe not pretend to make a long Narrative; the short stay I made in every of the places where your Majesty sent mee not allowing time enough to inform myself exactly of which otherwise I might have done.

The present Duke of Savoy was borne June the 20,1634, soe that he will bee this June, 1671, 36 yeares old. His father was Victor Amadæus, and dyed Octob. 7, 1637. His mother, who was sister to your Majesty's mother of blessed memory, after her Lord's death continued the administration of the government until the present Duke attayned the 14 yeare of his age, which was June 19, 1648, on which shee unexpectedly declared her regency to bee determined. This present Duke has been twice marryed; first in 1663, to Mademoiselle de Valois, daughter to his uncle the Duke of Orleans; but shee dying, as also his mother did before the end of that yeare, hee within few moneths after tooke to wife Maria Joanna Baptista deSavoy, commonly called Mademoiselle deNemours, shee being a princesse of his owne family, and unto whom hee must have payd a considerable dower if shee had marryed elsewhere. Shee is 27 yeares old, and has only one sonn, born the 14 May, 1665; and, as I find, they have noe great likelyhood of more.

The Duke of Savoy is vigorous, active, amorous, free of discourse, a great lover of buildings; hee spares no cost to accomplish his pleasures. Witnesse his pallace a la Venerie, built in a mountain, yet finished with all perfection, in a place of ill accesse, incapable of enlargement of gardens, courts, or parterres, without removing of hills or raysing vales, which yet this prince has atchieved in two or three yeares time. Hee delights much in hunting, as appeares by the building of this place, and is noe lover of the French; as the same place may alsoe witnesse, for hee has incomparably a better house, and a more convenient place for that sport, were it not scituated within view of Pignerol, the only argument as hee told mee himself that induceth him to come so little there. This prince's great earnestnesse in that sport is evident from severall escapes hee has had, almost to a 
miracle, of which I can give your Majesty a verbal accompt; hee has in his nature such a familiarity, as renders him beloved by all that converse with him.

This Duke is exceedingly beloved, I may say adored, by all his subjects great and small, from whom hee takes with moderation, though his government makes all lawfull to him. Hee is more mindfull of his businesse then hee seemes to bee, and has more money in his coffers then hee would bee thought to have. Hee is in continuall action, and though in appearance hee bee a man of pleasure, yet I dare assure your Majesty hee is very diligent in his affaires, and neglects noe matters of moment. Hee is out of debt and a good manager, yet abates in nothing which may tend to the advancement of his grandieur, as his guards, which for habit and armes are not inferior to any I have seen.

The Dutchesse is a most excellently accomplished princess, and exceedingly beloved by all that Court. I had the honor of seeing her often, not only en Ambassadeur, but en particulier, and severall times some houres together along with the Duke only; in which time I never observed her to say anything which had not weight and judgement in it, which together with her complaisance has I suppose produced that great power and interest shee has in the Duke, to such a degree as hee seldome acts anything of moment without her advice.

The Duke is of a black haire, and a sanguine complexion; not very tall. The Dutchesse is rather fat then leane; of a faire complexion, gray eyes, a round face, indifferent tall, and well shaped. They have only one sonne, who at my being there was just recovering of a dangerous sicknesse. If this prince dyes and the Duke have noe other children, that dukedome descends to the Principe di Carignano, eldest sonne to Prince Tomaso, that dyed some 8 or 9 yeares agoe at Turin, and was brother to the last Duke. The said prince, though dumb, is a lover, and has possibly one of the handsomest ladyes of that Court to his mistresse. The said Prince Tomaso's second sonne is called Eugenio Conte de Soissons, who is still liveing at Paris, and marryed Mademoiselle Mancini, Cardinal Mazarini's neece, by whom hee has severall children, two of which live at Turin with their dumb unkle: the eldest, il Cavagliero di Savoya, may bee some 9 yeares old; the other, il Conte de Dreux, about 7. I visited the unkle and nephews and was visited formally by them, of which I have some passages to relate to your Majesty, which possibly may not bee disagreable. These have all the title of Altezza, and pretend in the same manner as the princes of the blood of France to the hand of all ambassadors; but in my particular they were strangely respectfull, and avoyded any third place where I hapned to come. The father of these young princes has many other children, and is in a faire way of encreasing them. 
The Princesse Louise, who is the Duke of Savoy's sister, may have some 40 yeares of age; a very masculine woman, and has a great deal of witt; shee was marryed to her unkle the Cardinal, but never had any children. The women here doe not succeed in the inheritance of the State, though they doe in private patrimonies.

Though the Duke bee a soveraigne Prince, and may determine all matters forreigne and domestick as himself thinks fitt, yett hee has thought good to make use of a privy councill, composed of the persons hereafter following: the Archbishop of Turin, the grand Chancellor, the Marquis of Pianesse, heretofore Chief Minister (who though retired and leading a religious life, comes yet and assisteth at the Council, as often as hee is sent for, else not), the Marquis de Villa, knight of the order and generall of the artillery, the abbot d'Aglie, the Marquis St. Thomas, premier Ministre and Chief Secretary of State, and the Conte de Boutilliere his sonne, who has the reversion of that place after his said father, and now acts at this time jointly with his father as secretary of state; as his said father heretofore did with his father before him.

The grand Chancellor and Chief Secretary of State are of this Council by vertue of their places, the rest ad libitum Principis, and come not unlesse called; soe that when they dye those who succeed in their employments have not thereby any right to bee of this Council, unlesse the Duke think fitt to advance them thereunto on the accompt of their experience and merit, or his favour and good will.

But your Majesty may bee pleased to know that there are only two who may bee said to bee the persons on whom this Duke does chiefly rely in all matters abroad and at home. The one I have already named, the Marquess St. Thomas, who may bee 55 yeares of age but seemes much older, being of no healthy constitution; hee is subject to catarrhs colds, is rich, and desires to bee richer. Hee has been alwayes bredd up to businesse under his father, who was (as I have observed to your Majesty) secretary of state before him, so that it is noe wonder if hee bee well versed in the affairs pertinent to his function; though otherwise $I$ think I have conversed with many men of better talents. The other is one they call Generall Trucchi, that is to say, grand Tresorier, a man of elevated parts, but of low extraction; I finde the Duke relyes very much upon his abilities and fidelity, and to say the truth hee well deserves it. The manner of his being introduced into his master's service will affoard your Majesty a greate deale of satisfaction, as being full of passages very curious and not ordinary. I hope your Majesty will affoard mee the opportunity of relating it to you, it being fitter for your eare then for your eye.

VOL. XXXVII. 
This Government is monarchial, lesse limited then that of France, yet much better beloved then the other by his subjects, the reason of which your Majesty may collect from the caracter I have given of this Duke, who though hee has right to take from his people, not only what is necessary, but what hee is pleased to think soe, does yet make use of this prerogative with such moderation and treates his subjects with that clemency as render him wonderfully beloved by men of all conditions. I begin with the accompt of his debts, for I esteeme all Princes rich that are free of incumbrances of this kind, as the Duke of Savoy is; hee haveing payd those very great ones which his mother left upon him. The only remayning one is that of a million of crowns due to the Duke of Mantoa for Montferrat, of which 494,000 crownes of gold with interest for the same, the said Duke of Mantoa ought to receive from the Crowne of France, as was agreed at the treaty of Querasque.

Moreover the Duke has due to him the intire portion of the Infanta Catharina d'Espagna, which is a million of Crowns of gold, in right of whom hee is in a faire probability to succeed to the Crown of Spayn; being next heire, if the present King of Spayne and the Emperour dye issue-lesse. Hee has moreover very considerable summes in his treasure, and particularly in his Cittadell Ast, nor does hee value himself a little in being better provided with money and stores then any of his predecessors have yet been. The sumes which hee does receive from his people and from his own lands, court offices, and the like, in times of peace amount to 600,000 sterling; in times of warre much more. I am prepared to give your Majesty a particular accompt how and whence this treasure does arise, when you shall bee pleased to coñand it. His constant expences are about two-thirds of it, in his family, forces, buildings, \&c. so that hee layes up some 200,000 sterling p Añ.

As to the interest of Savoy and the Duke's present designes, soe farre as I was able to penetrate into them, I must acquaint your Majesty that this Duke, led to it not only by that generall policy which makes all Princes jealous and æmulous of their neighbours, but more particularly by a number of unkindnesses and incroachments of the French, is at a stand how to carry himself towards that monarch, who has already possessed himself of Pignerol, seated in the middst of this Duke's territories, and made, if not impregnable, yet very strong. Moreover, Dauphiné coasteth all the length of Savoy to the east from Beauuoisin to Suze, upon which place Chaumont borders within halfe a league. Some part alsoe of Dauphiné comes up within a league of Pignerol, and Briançon itself is but 18 miles English from it; soe that it is impossible this State can have any cordial affection 
for soe powerfull, soe neere, soe incroaching, and soe fierce a Prince. Hence it is he endeavors to entertain soe good a friendship with the state of Venice, and other Princes of Italy, as knowing they hold to be equally their owne interest to preserve him, hee being their outwork as it were, and haveing the keys of severall inlets into Italy; and hence it is that he covets your Majesty's protection, which hee has soe oft repeated in totidem verbis, and I may safely tell your Majesty, if this Prince has any partiall affection for any one, it is for your Majesty and your people. Some little disputes there are between him and the Genoeses, but themselves as well as their neighbours are sollicitous enough to accomode such differences; though for my part I should think this Prince as likely as any one to come to a rupture, in regard hee is hasty, resolute, full of courage, and an undertaker. Towards the French hee is somewhat sharp, to say no more, and the young Prince, his sonne, doeth patrizare. I have two or three pretty passages on the accompt of this Prince to informe your Majesty, which, though light in themselves, may yet serve to confirme your Majesty in the beliefe of some things herein offered to your consideration. This Prince has great pretentions on the Montferrat, and I am apt enough to think he may probably attempt something there. There are alsoe some jealousies passe between him and Milan; but haveing a prospect of succeeding to the Crown of Spayne, tho remote, yet possible; or peradventure in respect of the great power of that monarch in Italy, of which his country has had woefull experience not long since, hee is rather desirous to keepe faire with the ministers of that King, and especially at this time, when to weaken that monarchy were but to strengthen another, whom hee apprehends much more. This Prince, as the rest of Italy, would upon any occasion erect such another allyance or confederation in the East as your Majesty has in the West. In the meane time they all consider your Majesty as their protector and benefactor, not sticking to ascribe the peace they enjoye to your Majesty's interests and influences.

The militiaes of this Prince are divided into 2 parts-those of Savoy, and those of Piedmont. Savoy being a mountainous barren province, yields not many soldiers, but they are esteemed to bee stout and hardy. Hee can upon occasion draw 6000 able foot, but no horse from thence, the country indeed being hardly capable of keeping any; but Piedmont is the province that yields him both men and money. The province is divided into 8 parts, or quarters, each of which has a militia of 10,000 men, all armed and disciplined; and reduced into regiments and companies, under Colonels, Captains, and other appointed officers. These, on. occasion of invasion or warre, are to doe service any where in the Duke's domi- 
nions, and out of these his Highnesse may arme 20,000 foot, and 5000 horse, all select, expert men, very good, and as ready at their armes. I doe not remember to have seen a man out of his owne house but with his gun upon his shoulder, in any of those countreys, especially in Savoy, where the woods and hills affoard great store of game, and those his Highnesse can maintain without burthening or oppressing his people.

I will now descend to give your Majesty an accompt of the forces which hee entertains in this time of peace in constant pay; which are about 7000 foot in severall garrisons, besides the guards hee keepes about his person, which are one company of gentlemen archers, two companies of Suisse foot, a troop of Cuirassiers, and another of Arquebusiers. Madame Royalle has likewise two troops of the same, as has Madame la Princesse, in all six troops, admirably well appointed, and in good order. The riders are most gentlemen. The troops consist of 60 men each, and may be in all 400, officers included. His foot guards are 300. Over and above those, hee entertains a regiment of horse in Piedmont, consisting of 10 troops, which make 600 horse effective, who are ready on all occasions.

His territories are well garrisoned. In Savoy there is not a mile of ground but affoards many strong places, that is, scituations capable of impeding any force whatever. Montmelian, however, is the chief place of strength in that province, where hee alwayes keeps a strong garrison, and a large Magazin of Corne and Armes ; some of the French King's territories, and one of his frontier forts lyes within sight of it, that is to say, within 2 English miles on the way from Grenoble thether, in Piedmont. Hee has Turin, a strong town, regularly fortified, the walls of freestone, the graffs very large, and easy to bee filled with water in a few howers, nor have I any where observed a towne soe watered as this is. The Duke has also in Turin a cittadel after the manner of that of Antwerp, with a well in it, where 500 horse may goe downe and up to and from the water, without hindring one another.

Hee has also Verceil, one of the strongest places of Europe; yet the Duke goes on fortifying and adorning it, not with earth, but good brick and freestone. There is now a garrison of 2500 in it. Besides these hee has Trin, Verrue, Hyvree, Ast, where the Conte de Maffé is governor with a garrison of 2000 soldiers, Villeneufue, Albe, Carmagnole, Querasque, Cuneo, Ceve, Suse, the forts of Bard and Verres. In these there are garrisons, and in time of warre he can clap soldiers into many other good towns. Hee has also garrisons in the citty and castle of Nizza, Villa Franca, and St. Hospitio. The castle of Nizza is reported to bee a very strong piece indeed; but, if once beseiged by land, I should not think it long tenable, in 
regard neither this Duke, nor any of his ancestors, have ever yet attempted to keepe any vessels upon the sea, whereby to releive it that way. In these garrisons hee maintaynes the before-mentioned 7000 soldiers. Besides the places aforesaid, his Highnesse has many good citties well inhabited, and much bigger then Turin itselfe, as Saluces, Savillan, Fossan, Mondovi, Quiers, Chivaz, Brielle, Sainthia, Aoust, and others. His country is very well peopled, and Piedmont altogether as fruitfull as Savoy is barren.

This prince's Country is not very broad but long, from Pontbeauuosin to Verceil I esteeme it to bee 9 dayes journey at 30 English miles per diem, which is 270 miles, but in broadest parts it exceeds not 50 .

This Duke's country abounds chiefly in raw silk, of which shee sends great quantities yearly to Lyon, Paris, Tours, Genoa, Florence, all which places work up this pretious commodity, and many of their own silks soe wrought up are brought hither again and here sold; now indeed they begin to set up silk manufactores of their own, and both doe and may affoard to undersell their neighbours 25 and 30 per cent. And on these termes they say they will furnish your Majesties subjects with excellent goods of the several sortes.

They are very ingenious, industrious, friendly, sociable, and honest in their dealings; the Duke himself, as also his ministers, extreamely desirous to court the English above all others to begin a commerce here, to which end they have caused an exact mapp or charte to bee made of the port of Villa Franca, which I sent to your Majesty. They have alsoe opened the wayes in order thereunto between Villa Franca and the Po, for all carts and waggons to passe, which is not above 2 dayes journey; and then by the said river they can transport through all Lombardy, even to Venice, sugars, salt, fish, stuffs, spices, lead, tynn, cloth, callicoes, \&c., which now are landed at Genoa and Leghorne, and sent by mules over these and other provinces. Your Majesty may easily ghuesse that this conveyance being once opened, the trade of Genoa and Livorno will abate of what it now is. In order to this alsoe that prince did very readily as well as generously instruct mee with his part of the ratification of the treaty made by Sir John Finch, your resident at Florence, with the ministers of the said Duke of Savoy, for a free trade att Villa Franca; that part of the ratification which your Majesty ought to confirme, I am engaged by writeing and honor to see sent to him; and beseech your Majesty I may acquit myself of it as becomes mee.

This country can furnish your Majesty's subjects with wines, oyles, rossoli, corn upon occasion, orenges, leamons, sweets, all sorts of wrought silks, raw silk, ribbons, canvas, hempe, soape, strong waters. 
This Duke has but little extent of territorie on the sea, and his subjects lesse accustomed to traffic. It will bee then a work of time before they bee invited to venture much abroad, which is not the worse for strangers. This Duke being, as I have represented, active, and a great undertaker, he may, I presume, designe to buy or build some ships or gallies, as his neighbours doe, and, it may bee, adventure somewhat in trade on his own account. Hee is now every day encourageing and inviteing his nobility and gentry to looke into trade, telling them hee will ayd and help them on all occasions. I conceive it is your Majesty's interest to encourage the trade of your subjects there, and for that end to entertain an agent or resident in this prince's court for some yeares, the better to countenance and support it at its beginning; and if your Majesty's subjects shall neglect this trade the Dutch will certainly stricke in with it, and that very soon.

Your Majesty will now permit mee to vary from the methode I have observed in my accompt of Saroy, the government of Genoa differing from it in all respects, soe that here I shall not trouble your Majesty with the relation of the governing family, or the persons who now are in credit, in regard that once in a yeare, or lesse, they are all removed. I shall therefore here, as alsoe at Venice, observe to your Majesty the manner of their government; secondly, their revenue, extent of territorie, forces, and trade; lastly, their present interest and designes.

The government of Genoa is aristocratical, where the patricians beare sway, who may bee neare 700 families besides absents; and such that have not attained the age of 22, till which they admit none into the grand council. Part of the Plebei are sometimes added to this body upon the account of money or merit. Out of this great council two hundred are every yeare elected, who ought to be at the least 27 yeares old; but $I$ think the age is not alwayes exactly observed. Those are the lesser council.

There are two Colleges which preside over these 2 councils; one of 12 senators and the Duke, the other of 8 procurators and all such as have been dukes; which generally make this college consist of the same number with the other, as it does at this present, but not alwayes. These in conjunction are called Sereni Collegi, and treat of the most weighty affaires.

The Senate may call the procurators to attend them when they please, and they goe not but when called.

The first weeke in January these two colleges meet and convocate the lesser council, to the end the said council may make choice of 30 of the best cittisens, 
who are to elect the lesser council for the next yeare. The said 30 meet the next day, and out of the body of the great council doe elect 200 for the purpose aforesaid, which they generally dispatch in 2 or 3 dayes, soe that by the 12 or 15 of January the new lesser council is in execution of their authority.

Generally they choose the self same persons; with some variation in respect of such as are absent or dead.

The senators or procurators are chosen by the ballot in this manner: there is a box called bussolo del seminario, into which the names of 120 of the nobility are put, each being 40 yeares of age. Every six moneths they draw out five, as it happens; the three first are senators, the 2 last procurators for the two succeeding yeares.

For the constant filling this 120 the lesser councils meet the beginning of June before the two colleges, and each of them gives in the name of such persons as hee thinks fitt for the degree of a senator or procurator, who must bee 40 yeares old; then the whole council proceed to vote thrice upon every such name, and haveing considered how many are wanting to supply the 120, they set apart double that number, and soe carry them before the grand council, who out of such double number elect soe many as make up the 120 , when either the great or lesse council meet. It must bee by the convocation of the two colleges, who must alsoe bee present.

When the Duke's two yeares bee expired, his successor is thus chosen as followeth : the colleges summon the great council, who being assembled are first numbred, and soe many balls made out as there are persons, of which 50 are guilt, the rest sylvered. The colleges draw noe lot, neither are any balls put in for them, in regard they cannot propose any man to bee Duke, but are afterwards to give their votes, as I shall informe your Majesty, they that draw the guilt ones retire, each man writeing downe the name of him whom hee thinks fitt to bee Duke, who must bee 50 yeares of age. Most times persons soe nominated by the said 50 are 20 at least, it being rarely seen that any three agree in one man; and, indeed, they must continue to propose untill twenty several persons are proposed. As soon as twenty are nominated then the said 50 proceed to vote man by man, and those 15 who have most votes are set apart to bee the next day proposed to the lesser council, who doe the like, and those six who have the most votes in the said lesser council are carryed back again to the grand council, where hee of the said 6 that has more votes is Duke, and in all those votings or ballotings the colleges have a part.

The said Duke and two senators may determine authoritatively some small 
matters, and in case of urgency great things alsoe, but then they must immediately have recourse to the senate or colleges for their approbation.

Though the Duke and senators represent the State, yet are there those that judge even of the actions of every one of these. The Duke and colleges may doe all things not particularly by law excepted; as, for example, they may determine all civill controversies, or referre them to be determind; they can adnull or confirme wills and contracts, in a word, they rule and govern. In criminall matters neither they nor any of the nobility intermeddle to avoyd injustice, mallice, bribery, revenge; but they have forreign judges, whom they alsoe change every two yeares.

In all cases where the being of the State or Government is concerned both the colleges must meet and consult, sometimes calling on the lesser council to ayd, and in extraordinary cases the greater, in either of which two councils there are alwayes present 5 conservators of the lawes, who are to see that nothing passe contrary to law; and tho they have municipal lawes, yet to comply with exigency of times and other occasions, such lawes may bee altered or abrogated, the manner of which is thus : If the great councill propose, it must bee to the two colleges, who represent it to the lesser councill, and they again to the greater, where, if it then passes, it is a law; or else the two colleges propose it to the lesser council, and they carry it to the greatest one, and if there it passe it acquires the force of a law ; but now, lawes which doe not alter or abrogate old ones may bee proposed by the two colleges to the lesser council, and if it passe it is a law, without the concurrence of the grand council. But over and above these two colleges and councils they have other peculiar magistracies for particular functions, it being thought unreasonable that the 2 legislators should always sit, and it is impossible the two colleges alone can determine all matters that would come before them.

They have 7 inquisitors, whose care is to prevent all publique dangers.

There are six who oversee all things relating to warre.

There are 5 who superintend granaries and stores.

And as many that consult all things relating to boates, ships, and gallies.

There are other $\mathbf{5}$ who supervise the walls, wayes, streets, moles, and aqueducts.

There are other 5 who regulate markets, weights, measures, and prices of all comodities.

They have 5 called syndics, who censure the actions of all such as have any publique authority or employment of what soever degree, high or low; but in case these syndics find occasion to proceed against any duke, senator, or procurator, whilst such, they must inform the lesser council of it, which said council (the 
said 5 syndics presiding) may take cognisance of it, and acquit or condemn without convocating the 2 colleges or the greater council; and in all cases where the syndics alone condemn, an appeale lyes before the lesser council, but from thence not. In the last place they have certain magistrates called the protectors of St. George's howse, who are of very great authority in this state. The occasion of their erecting was this : In times of long and chargeable warres, when the public moneys were exhausted, this, as all other states, was forced to borrow money, and to farme out to such as would lend the public rents and incomes. To the end such lenders might bee secured, the commonwealth gave them authority to elect 400 out of themselves, whose duty it was to see that all such creditors were duly payd; and to the end the credit and interest might bee more reverenced, the commonwealth intrusted them with the priviledge of choosing the 8 procurators, together with some magistracies also. These take cognisance of all controversies, and crimes relating to public monies without appeale; they lett to farme, and receive all the customes, gabels, farmes, \&c., and the powers they have are most religiously observed; whence it is that strangers and forainers repose such trust and faith in them as to leave their moneys in their banks, of which there is constantly in this treasury upwards of 5 millions of scudi d'oro; nor was it ever seen or known, in the greatest warres and calamities, that the state did soe much as cast an eye towards this treasury-a howse soe sacred, that even the heyres of condemned traytors, nay, traytors themselves, both before and after condemnation, have received and disposed of the sumes they had there deposited. Moneys here kept. beare no share of the publick charge; and if any will let out their moneys here to the public they may receive $2 \frac{x}{2}$ interest, and what the state can advance over and above the said $2 \frac{1}{2}$ is employed in public works, - as the New Mold, a work great enough for a monarch to undertake; the new Lazaretto, capable of receiving 8,000 people; Fortifications wherein they spare no cost, as at Savona, Vada, and especially Corsica. Besides, the Stat has of their owne 5 millions of scudi d'oro in banke there.

The revenue of this state ariseth chiefly from their customes; as, for example, they draw yearly from that of wine

From that of oyles

From seminaries . . . . . . . 120,000

From corn . . . . . . . . 100,000

Tabacco . $\quad . \quad . \quad . \quad . \quad . \quad .100,000$

From goods exported . $\quad . \quad$. $\quad$. 200,000

Goods for strangers imported . . . 200,000

VOL. XXXVII. 
They alsoe draw considerable summs from anchorage of ships, portions of woemen, creating of gentlemen, fines, forfeytures, amerciaments, which amount

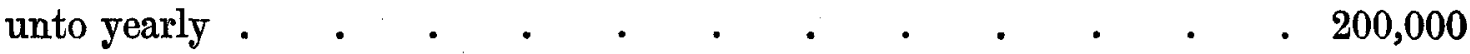

Maritime towns and inland citties doe alsoe helpe to encrease the public revenue to a considerable degree; many are at a certainty with the State, some more, some less. Séstri alone pays yearly . . . . . . . . . 100,000

Nor are the private persons lesse rich, the moneys of this state setting the law and exchange on all the moneys and trade in Europe; and well they may bee rich in moneys, seeing they are soe poore in land, their country being little and barren, soe that there is noe roome left to lay out any thing in purchasing, but are forced to keep their moneys at interest in trade, or, which is worst, dead by them.

Vintimiglia is the frontiere towne from Genoa towards the west, and is distant from it one hundred Italian miles; not but that Final, which is the King of Spayne's, and Oneglia which is the Duke of Savoy's, intercept their free passage by land; besides, the Duke of Savoy layes clayme also to Savona.

Her inland territories are very narrow, the broadest not exceeding 20 miles, and in many places not eight; the generality of it also is mountaynous and barren, though they have some vallies rich in abundance, both in fruit and corn, as some of their hills are in olives, chesnutts, and vines.

It has eleven walled citties. It has one archbishoprick, viz., of Genoa, and six bishoprics, towards the west. It is limited by the river Varo, and towards the sea by Macra.

The forces of this and of most republiq' consist more in mercenary soldiers then natives, soe that upon occasion they use to hire 10,000 or more as they have occasion; their pay is good and certain, so that they cannot want; now that they are in a secure place they entertain 2600 soldiers in severall garrisons.

They have in and about their citty 8000 who are of their militias, being listed and reduced into companies and regiments, but they rely not much on them, as indeed none of the princes of Italy doe on their owne countrymen; who generally are effeminated and enervated either by vice, peace, or luxury; for sure it is they inherite not the ancient courage or vertues of the Romans and Latines; but Genoa need not much feare; her country being almost impregnable through the barrennesse and rockinesse thereof; they live therefore in too great security to be good soldiers in fight, whatever they may bee in handling their armes: the Genoeses have some places very well fortifyed and strong by nature also, as Savona, Gavi, and Santa Maria; in Corsica they have Bonifacio and Calvio, two very strong places; Corsica and Liguria together (for soe the state of Genoa is called) may 
have 70 thousand lusty men, fit enough for warre in respect of body, but not to bee much relyed upon: 45 thousand of which number are of the terra ferma, the other 35 thousand of Corsica. Genoa has alsoe an armory with 30 thousand good armes in it. This state has now six gallies and is building six more; she has alsoe 2 men of warre of 60 guns each; besides there are alwayes kept 6 gallies more by private persons in their port for the service of the King of Spayne, who payes them yearly 60 thousand livers each, soe that the proprietors of those gallies have noe ill time of it, seing they seldome are upon service, and they let their slaves shift for themselves. This state has some 1500 slaves, Turks and Christians, for their gallies; and besides these they have neere 2500 slaves more in the town, whom they make use of about domestick occasions.

This State does every 2 yeares make a cense of their houses and inhabitants; the last was of 25,000 houses, and somewhat under a hundred thousand inhabitants. This disproportion ariseth hence; in $\mathbf{1 6 5 7}$ they laboured under a great plague, which from 100,000 they then were reduced to 50,000 , by which reason very many of their houses are yet uninhabited; nay, in some whole streets few people are to bee seen; yet such is their pride and ostentation that they goe on building, and $I$ believe in a few yeares they will have filled all that vast mountainous space of ground which lyeth behind the city inclosed within the outer walls which are 8 miles about, with pallaces, villas, gardens, houses of delight, and the like. One great reason of the paucity of their inhabitants I conceive to bee, the men seldome marry till they are forty, and then for the most part their power of propagation spoyled; another is, the draynes of religious houses. There are about 100 Jewes, I meane public ones, that live in this citty; and in truth a stranger would judge most of the men and women hee meets were of that nation; but I doe not think that the Genoeses are, as their malicious neighbours say, Jewes, in regard they are too hard and crafty for the Jewes. In all other places of Italy the Jewes thrive and live well, here they are all beggars, and cannot get a subsistance.

The trade and commerce stands thus : they furnish England with argal, soape, hemp, rice, oyle, oranges, leamons, paper, corall, silkes of all sorts, and marble; they receive from us all sorts of woollen manufactures, lead, tynn, hydes, tobacco, sugars, fish, all sorts of Indian commoditys, linnings, spice, dying wares, druggs, \&c. most of which they transport over land by mules and waggons into Lombardy and up to Venice itself.

The Genoeses use all strangers very ill, and your Majesties subjects as bad as any; their nobility are all traders, but when the merchants have any demands, however just, upon them, it is impossible to procure any right against them. There 
are many complaints of this kind now on foot. I endeavoured what I could in it ; brought away very faire promises that all should be ended according to my desires, but since I find nothing effected. I foresee your Majesty will have applications made to you to use some more effectuall meanes to procure them to doe your subjects right, and I think your Majesty might give them a great blow by encouraging the trade at Villa Franca, and causing your marchants to withdraw from Genoa, at least threatning them with it; this is certain, when once the trade of Villa Franca is open, Genoa will loose very much of the commerce she now has. Possibly in this juncture of time, and dureing the jealousy this state has of Villa Franca, your Majesty might obtayne considerable advantages by a body of articles from this state for your marchants, if your marchants think fit to continue a trade there; and at the same time procure them to doe your subjects reason, whereas now their nobility are in truth above the law, which makes it a businesse befitting your Majesty to interpose in. I believe there may bee at least $£ 20,000$ sterling due to your subjects, which the respective debitors are well able to pay, but cannot bee compelled to it for the reasons aforesaid.

Genoa was running altogether into Spayne, even when Spayn was in its height, contrary to the policy of all the rest of the Italian princes and states; the truth is, they drove a great trade with that monarch both in Spayne and the Indies, lent him moneys, furnished him with gallies, men, ammunition, \&c. conformed themselves to the Spanish habit, and in a word were in a faire way of being swallowed up by that monarchy, many of her greatest nobility being suspected to have such designes; but at length the State being advised of it began to looke about and court the French, not soe much for love to that nation as to their own preservation, and this they did notwithstanding the French King styles himself Lord of Genoa.

They alsoe discountenanced all such as were of the Spanish faction, and have opened a commerce between Provence and their citty, by which the are furnished with all sorts of provisions, which formerly came from Sicily, Naples, \&c. At this time the rest of their neighbours esteeme them to bee right set for the public interest of Italy. Genoa has noe jealousy of any neighbour but the Duke of Savoy, whose pretences upon Savona keep them on their guard; but that Duke will find it difficult to force that town from them soe long as hee has noe ships nor gallies of his owne able to master them, unlesse some prince powerfull at sea should ayd and assist him, and in such case I conceive the difficulty would not bee very great, for that the territories of Savoy lye very neare it, and 'twere no difficult thing to bring 10,000 men before it in 3 or 4 dayes time; the place, however, is very strong both by art and nature. 
I parted from Genoa in a gally assigned mee by that republiqe, according as your Majesty's commands directed me, to Livorno, where at my disembarking Sir John Finch informed mee of the grand Duke's death, who in the time of his sicknesse (out of a true sense of the honor your Majesty had been pleased to doe him) had given such orders for my reception as, being continued by his successor the present Duke, though my credentials were not directed to him, yett was I received with all the honors and respects the father could have shewn towards mee. Hee received your Majesty's letters of credence, though addressed to his father, and entred into a treaty of negotiation with me for the bettering the condition of your subjects who trade at Livorno; in all which hee expressed a great kindnesse and propensity to comply with anything your Majesty could desire from him. True it is I was not received with some public testimonies of joye usually practised towards others invested with that character your Majesty had been pleased to honor mee withall, in regard his highnesses father had not been dead above 10 or 12 dayes, otherwise I dare assure your Majesty there was nothing left unsayd or undone that might expresse even the greatest deference and observance towards your Majesty in the person of your unworthy minister.

I was defrayed from my landing to the last towne in his territories: his highnesse also caused his letters to bee sent to the legates of Bologna and Ferrara, by which places I was to passe, to advertise them of my qualification, and to dispose them to treat mee with that honor which is due to your Majesty's servants in the condition you had put mee; hee sent mee also a present, which your Majesty has seen, the first I had received since my comeing out. I am the more particular in these things, that your Majesty may see what impressions you have made in the minde of that most excellent prince, who I am sure is a passionate lover, as well as great admirer of your Majesty.

I shall hold myself excused from giveing your Majesty any character of him, since hee is personally known to you; neyther need I say much of the Dutchesse, whom your Majesty cannot but have seen in the court of France, by whom hee has only one child, a sonne, of some 5 yeares of age, who seemes not to bee very strong grown. The Duke has one brother also, il Prencipe Francesco, a youth of 11 or 12 yeares of age; no very strong constitution; whose province it is by the custome of this court to receive all ambassadors at their comeing, and to conduct them at the departure. This Duke has one unkle liveing, the Cardinal de Medicis, who at my being at Florence was at Rome, so that I can say little of him.

It was the common voyce of all men whilst I was there that the present 
Duke would pursue his father's way of government: at that time hee had not made any change in the governors his father employed, nor since, as $I$ heare, Marquis Richardi excepted. It is believed hee will prove a prince of singular esteeme, in regard of his many good qualities; that hee has seen the world; and is very generous, in which some of his family are thought to have been a little deficient.

This prince governs by himself in chief, and for his ease hee is pleased to have a cabinet council, as his father had, which yet consisteth of 2 persons only besides himself, the Marquis Ricardi, who is chief steward, and Conte Bardi, who is Secretary of Warre and Chief Minister. Hee has the Conte de Nouellari, who is Lord Chamberlaine, and in great favour, as is also the Marquis Vitelli, captain of his guards. The master of his horse is Marquis Corsini. Marquis Cerbon del Monti is master of the warderobe. Danti di Castiglioni, who attended his highnesse in England, is first gentleman of his bed chamber. Signor Leonardo Tempi, a marchant, but a gentleman, is a treasurer. These are all in good credit with him, and hee adviseth with them as hee sees occassion, but communicates little of his secret thoughts and designes to any but the two first, who are of his cabinet council. Ferrante Caponi and Auditore Farinola are his judges in causes criminal, the first being alsoe his atturney generall in his ecclesiasticall matters.

The grand Duke's territories are not very well peopled, nor indeed is any part of Italy, soe occasioned chiefly by the church, which draynes them exceedingly; but as to his dominions particularly other reasons may bee assigned, which, perhaps, are not soe fitt to be named. I will observe to your Majesty one I remarked between the two towns of Pisa and Livorno. In the former there were once four hundred thousand inhabitants, and they frequently entertayned 130 or 140 gallies at sea at such time as they contended with Venice and Genoa, but now it lyeth desolate and uninhabited, haveing scarce 10,000 soules in it, and of those at least one-third appertayning to the church, there being 22 monasteries and 17 nunneries in it, the least of which has sixty persons, and many one hundred in them; besides, there are at least 500 secular priests who are not in orders; the town miserably poore, in many streets not an inhabitant, but grass growing in all of them; and, since I am on the subject of the church, I begg your Majesty's permission to make a short digression. It was my hap to dine at a monastery of Franciscans between Livorno and Florence, where I was entertained by the Grand Duke's family. In the church I found a printed paper, contayning the summary of a Cense made of their order in 1648, at which time there were 180 thousand men of it, and 210 thousand women,-farr bee it from mee to call them maydes; 
and lastly, 26 thousand howses of this order then standing. I submit it to your Majesty to make inferences and deductions; but to returne to Livorno, between which and Pisa I was making some kind of corollary. Livorno, which within these threescore yeares had not 1,000 inhabitants, is now by trade encreased to thirty thousand, of which say they there are 9,000 Jewes, 6,000 strangers, about 1,000 soldiers, and the rest Italians; but for my part I think they reckon 6,000 too many, for I cannot conceive how soe little a place can contayne soe many people. They begin to complaine of the decay of trade; that is to say, that the Grand Duke's own subjects doe not consume soe much as formerly they did, and some observing persons there are who impute it to the decrease of his subjects. The last Grand Duke made it his businesse to keep them poore, which 'tis thought has made them also fewer, as well as poorer ; many of them retiring dayly, especially of the Pisans, into other states and territories; but I would not have your Majesty uninformed that the Pisans, being a conquered people, doe abhorre the government and family of the Medicis, soe that possibly these dukes may have reason in what they doe, especially if faire meanes make no impressions on them. As Livorno is the only place of traffic in this Duke's territories, soe is it alsoe of strength, and guarded proportionably. The fortifications are very regular, and well mayntained. They were designed by a subject of your Majesty, though hee withdrew himself from his country, old Rob. Dudley, the titular Duke of Northumberland, whose sonne I saw at Bologna. The towne has 4 companies of foot in it, the governor's consisting of 350 men, the second company consisting of 250 , and the two last each of 200 , in all a thousand ; most Germans ; none of the princes of Italy affecting to have their own subjects acquainted with the use of armes. The governor of the town is the superintendent of the justice, the governor of the armes is a separate thing, and they are not subordinate to one another, soe that between these two there used to bee often peekes and grudges, but at present they, being brothers, agree very well. Their names are Sacrestero, and the later is a knight of Malta. There are two other governments within this place, independent and separate, who act by orders and directions from Florence, and are not under the governor's command, viz. the old and new forts. The captain of the port too has separate commission, and is not under the governor's authority. The designe of this multiplicitie of officers is to prevent any intelligence amongst them to the prejudice of their lord and master. Sir Bernard Gascoyne had been governor of the towne without all doubt, had not the late Duke's favorite, and who was Sir Bernard's friend and kinsman, dissuaded the Grand Duke from it, upon this single account, that there being frequent disputes and æmulations between your Majesty's subjects, the Dutch, and other foreigners, it was to bee 
feared Sir Bernard's affection to the English might induce him soe farr to take their parts on all occasions as to disgust the others, and force them to forsake the port, to the ruine of the trade there in a great measure.

Florence may have some 70 thousand inhabitants in it on a strict account, and all the Grand Duke's subjects doe not exceed a million and a halfe, soe that your Majesty may compute his strength. His revenue is at the least 400,000 sterling per annum, which he drawes from his customes, gabels, land taxes, the church, his owne domaines, and trade. His expences doe not exceed the one halfe of it, soe that it is conceived hee may have at least three millions and halfe of pieces of eight in banco, besides a vast treasure in gold and sylver plate, pictures, jewels, and such like curiosities.

Hee keeps many garrisons on his frontiers towards the Spanish and ecclesiasticall territories, but they are in small forts rather then great towns, and not above 100 in a place, in all to the number of 2,000; most foreigners.

Hee entertaynes only 3 gallies; his predecessors usually kept six and.seven, but reduced them to the aforesaid number, finding them of late to bee uselesse; the style of sea affayres altering as factions doe at land. Noe galley can withstand our new fine light-sayling frigates.

These two gallies your Majesty has ordered to bee built at Genoa and Pisa went but slowly on before I came thither; how they have done since I know not.

The Duke's port of Livorno is the scale of trade of all the Mediterranean sea, and it is a magazen where our comodities of spice and linning are landed, to bee afterwards dispersed over all Italy, into Turky, Barbarie, \&c.

They receive also and disperse great quantities of your Majesty's cloth, lead, tynn, stuffs, fish; and your Majesty's subjects there made certain proposals to mee for the removing some impediments, and procureing other advantages in trade. I transmitted them to my Lord Arlington, after I had represented them to the Duke, who received them with great readinesse, and assured mee of his propense desires to doe every thing that might ease your Majesty's subjects in their commerce within his states. The little stay I made there rendered it impossible for mee to perfect them; besides, your Majesty's instructions directed the leaving that province to your Majesty's resident there, Sir John Finch. This I conceive a fit juncture of time for your Majesty to procure a body of articles and concessions for trade there, which may secure and preserve many benefitts to your subjects. I will give your Majesty two reasons for this my judgement; first, I conceive the present Duke to bee well inclined to your Majesty's person and people in regard of his knowledge both of the one and the other. I am sure hee professes it very much. Secondly, I conceive hee is jealous, least the Duke of Saroy by his franck 
procedure in his treaty should draw away your merchants to Villa Franca, a place as well seated and adapted for trade as any port of Italy ; and the people I conceive much better, they being not soe crafty, jealous, and unconversable as the Italians; neither soe light and inconstant as the French; but of an open, honest, affable genius.

All the princes and states of Italy who border on the sea are contriveing, $\grave{a}$ l'envie of each other, which of them shall draw more pigeons to his dove coate; soe that your Majesty may prevaile on this occasion to obtayne any thing in reason which you can propose. I foresee only one obstacle which your Majesty will find a difficulty in, soe priest-ridden they are all here, that I feare it will bee impossible to obtayne any exercise of religion for your merchants, who though I think have noe great concerne for any such priviledge, yet it would redound much to your Majesty's honor and interest, as you are a Protestant monarch, if the freedom of such exercise could bee obtayned. The Grand Duke, as soon as I proposed it to him, did most readily assent to it, as a thing which hee thought would bee acceptable to your Majesty as well as advantageous to trade itself, provided the merchants would use this indulgence with that discretion that the Pope might take noe umbrage; assuring mee hee for his part would not recall it untill the Church took notice of it, whom hee was bound to obey right or wrong; adding, the Church would not take information of it unless they were too open and scandalous (soe hee tearmed it) in the exercise of it. Hee was pleased to confirme this once and again; but $I$ perceive now of late the Church stormes against Venice, Genoa, Legorne, and Savoy, for some connivances in this kind practised in the three first, and promised by the last alsoe. In Venice the inquisition is nomen inane, that State holding fast their authority in ecclesiastical as well as civill matters, and they find it drawes a great confluence of marchants to them who have freedom in religion; Genoa attempting the other day by their ambassador at Rome, Il Signior Durazzo (who had the same character here to your Majesty), to obtayne the like exemption from that jurisdiction. The Office fell upon the debate of Florence and Savoy, which I have before observed to your Majesty, and which is now in agitation. Since my takeing leave of the state of Venice, the Venetians have indeed got some little head of the Church, but the rest of the states of Italy are in great awe of the Pope, soe as in these cases they dare doe nothing that may clash with their holy father, who can arme even their own subjects against them, especially if they bee second and third-rate princes.

Touching the interest and present designes of this family, though they were advanced to their state by Charles the 5th, whose natural daughter Alexander de VOI. XXXVII. 
Medicis the first Duke marryed, yet they soon began to weane themselves from the interests of the howse of Austria, as knowing they who made them might easily unmake them; soe that for their own preservation they openly courted the French, and continue soe to doe to this day, though at present it bee upon other motives. The territories of the Grand Duke are every where surrounded by the dominions of the King of Spayne and the Pope, soe that both the power and vicinity of that King makes him jealous and vigilant upon all his motions. His policy and interest is to mayntaine the peace of Italy, and though hee courts the French, yet it is not with any designe of bringing himself under that protection, nay at this present both the Grand Duke, as all the rest of the princes, who are content with their portions, are rather afrayd of the French then of the Spanyard, the condition of those 2 monarchs haveing received a mighty change within this 40 yeares, which has also changed their interests, unto which they are very constant; they doe owe, and all impute, the peace they now enjoye to your Majesty's wisdome and influence in the triple allyance for which they own you as their patron and benefactor.

I find all the princes of Italy contriveing wayes rather of finesse then force for their support; which makes mee doubt there are few of them to bee relyed upon in any league, soe apt they are to play fast and loose, as it best suites with their humors and designes.

I shall not bee more particular in the relation of this Duke's territories, interest, revenue, or present posture, in regard your Majesty has entertained a minister soe many yeares in that place, who, being now upon his returne, will bee able to give your Majesty both a more exact and fresher account of that court; from whence, after 3 dayes' stay only, I departed towards Bologna, where the cardinal legate sent severall coaches with six horses to meet mee, and, within halfe an houre after I was alighted at my inn, sent mee a present of all sorts of provisions and confitures, which I acknowledged to him by my secretary, who was received by him very civilly. The next day I passed forward to Ferrara, where I was met with the same entertainement, and observed the same method; and soe to Venice; where I continued 20 dayes incognito, partly to get my gondolas ready, and my house (the biggest and best in Venice) furnished; but principally I was detayned soe long by a difficulty the college made to receive mee in the Cloyster, which I insisted upon, and was at length after long disputes granted. The case being not ordinary, I shall humbly beg your Majesty's permission to acquaint you with it before I fall upon the relation of that government. It has ever been the Venetians' custome to receive ambassadors in a certain island called Santo Spirito (antiently a convent 
of fryars), 5 miles distant from the town, to which place a cavalier of principal quality, attended by 60 senators in their robes, are appointed to meet them in an upper roome, where the ambassadors did constantly give the hand to the said cavalier, from the chamber where he was received unto his gondola, by reason that chamber and place was understood to bee the howse of the said ambassador. This practice constantly continued till about 6 yeares since, that the Count Sernini, extraordinary ambassador from the emperor, to avoyd giveing the hand would needs bee received in the church, alledging that to bee a third place, and consequently the hand due to him, which after some dispute was yielded to by the senate.

Not long after this, arrived an ambassador from Spayne, who insisted upon the same priviledge, and had it granted; but the cavalier arriving in the church went strait up to the altar, and there kneeling down, as did all the senators, left the ambassador standing alone for some time.

This present French ambassador, who arrived some moneths after, had the same successe, but in some measure avoyded the affront, by kneeling down at the same time with them.

This put mee upon the difficulty of a hard choice, either to receive the said cavalier in my chamber, and consequently give the hand, or in the church, where, being the minister of a Protestant prince, it was impossible to avoyd the same affront they had before given to the Spaniard; to obviate both which inconveniences, I demanded permission to receive the said cavalier in the cloyster, which being a third place hee could not pretend the hand, nor myself meet with any neglect by his going up to the altar; but this was for several dayes absolutely refused, untill they understood plainly from me that I could not make my entry upon other terms untill I had received your Majesty's comands from England; and that I believed your Majesty would call mee back, which apprehension prevayled with them (though very unwillingly) to make me this concession.

I shall not further trouble your Majesty with the circumstances of my entry, or other ceremonies relating to it, which, I may say, was not short of any that had, ever preceded; but fall upon the relation of the government itself.

The government of Venice is aristocratical in truth, though it have the appearance of the monarchical, and somewhat of the democratical too.

The supreame power and authority of the commonwealth resteth in them who are at this time about 700 of the nobility, and forme the body of the great council. Hence it is that this government has some shew of being popular, seing there are soe many who have a share in it, and that the vertue or wealth of the cittisens may open the dores of the nobility to them also. 
1. The Great Council.

2.

The Senate called Pregadi, because they were pregati $d i$ venire al consiglio as often as occasion required the meeting of them. The last 60 are chosen by vote, not lot, to the end judgement not affection should elect them.

The Procurators of St. Mark that were added gave during the warre $20,000 \mathrm{D}$. each for that honor, but as they die, they are not to bee filled up, but reduced to 9 again, who are still called of merit as the other are of money.

3.

The College.

4.

The Duke or Doge primicerio is overseer of the wax candles and lampes, \&c.
This Great Councill does dispense much of its executive power and authority to other officers and magistrates, yet still retaynes their primitive right in the enacting, abrogating, and amending lawes, in distributeing magistracies, in conferring dignities, and the like. These choose the Duke, create the College, erect the Pregadi. In a word, this is the mayn spring that gives motion to all the other wheeles of this government.

The Pregadi are properly the senate, to whom the grand council reserveth matters of peace and warre, the supervisal of the introitus and exitus of the public treasure, imposition of new levies or subsidies, creating new temporary offices, matters of state, and the most important affaires of the Republic. Antiently this council consisted of 60 only, called ordinarij; afterwards 60 more added as their government enlarged, called della Gionta. In processe of time the whole criminall council of 40 . All the college consisting of 26 .

The Council of $\mathrm{X}$, consisting of that number in this our computation (though otherwise, the Duke and the six councellors of the college are added to them, which makes them 17); the Procurators of St. Mark, originally 9 only, now 36; the master over salt and corne; all Ambassadors after they returne from their embassies, and some others who have undergone public and weighty employments: soe that at this time they consist of 276 .

The College consisteth of the Duke, six counsellors, one for every of the six quarters of the citty, three Capi, or heads of the 40 criminal judges, six Savij grandi, five Savij di terra ferma, and 5 Savij alli ordini; in the whole 26.

The Duke has little or noe authority besides that of makeing the Primicerio of St. Mark's church. Some few cannons' places hee disposeth of; and some few offices not pertayning to the government. Hee has nothing of soveraignty but the names, title, and a ducal capp; yet they allow that moneys should bee coyned in his name, but not by him; and public letters are directed to him. Hee has noe guards, is rather an honorable prisoner than a prince; but one supreame Prince they would have, to fill a place which otherwayes some man's ambition might aspire to.

They choose them old, to the end the dignity may passe into many families in a little time. His servants are all hired by the state, and payd by them too. They seldom choose any whilst he is marryed, yet hee is the fourth or fifth only that ever was soe chosen.

Hee never stirs his cap but to a soveraigne prince or cardinal. The Doge, with 3 of the 6 counsellors of the purple robe, and one of the three Capi of the 40 criminal judges, forme the representative of the State, or body of the Prince. 
The six Counsellors are chosen, viz., one out of every of the six quarters of the citty; the oldest in sicknesse or absence of the Duke, is a kind of Vice duke, for hee takes his place, and heares all those causes which the other ought to doe. They hold but eight moneths, dureing which the Duke does nothing without them.

The three Capi, or heads, of the 40 criminal judges, have place in the colledge in the right of the said magistracy : of these more hereafter.

The six Savij grandi, or Savij del consiglio, after the colledge is up, retire with the five Savij di terra ferma into a consulto, where they discourse, digest, and prepare matters for the senate, which are carryed thither by the Savio of that weeke (for they take their turnes), and in his time hee may propose what hee pleases.

The Savij di terra ferma are 5, and of a lower forme then the former, yet they retire and consult with them. They have a vote in the colledge, but not in the senat. They choose two amongst themselves, one to bee cash keeper, who receives Savio cassiere. and payes all public moneys according to order, and the other to secretary or superintendent of the Militias. The Savij alli ordini are five, and are young men, who have place in colledge, only to heare and observe the methods and rules of government. Now the businesse here transacted are matters of petitions, opening of letters, receiving of ambassadors; unto whom for the present the doge gives some general answer of respect; the point of businesse being reserved to the Senate, and this is all they have in a manner to doe.

The Procurators of St. Mark were formerly 9 only, now 36, the 27 which are added paying money for it in the warrs, and are thence styled Procurators of Money, as the other nine are of Merit. They have place and vote in senate, are exempt from ambassies, unlesse extraordinary ones, as also they are from governments, many of which are very expensive. They are of great honour, and hold during life. They have, however, but little authority, unlesse it bee the oversight of St. Mark's Church, of orfanes, and pupils, and some such like charitable matters. They enter not into the Council of $X$, nor into the Great Council; but when the great council meets, the procurators ought to bee in the court to direct and command the officers of the arsenal, who are then there as a guard. They goe all in scarlet, as the Duke does.

This Council of $X$ consisteth now of 17 . The Duke and the six counsellors being added to them. This council is exactly of the nature of our cabinet councils, as they are now used in England, France, Spayne, \&c. with two differences, first, the Duke enters not, but when sent unto ; secondly, they have infinitly more authority to heare and determine the very greatest things ; they can judge the Duke himself, or any other magistrates. Their generalissimi after their three yeares service

Procurators of St. Mark, vid. ant. paragraph 2.

6.

The heads of the quarantia or 40 criminal judges.

Savij grandi. Savij alli ordini. 
12.

The counsel of the 40 criminal judges.

(uarantia civil vecchia.

Quarantia civil nova.

I'resent state of Venice, 1670.

In relation to the peace and the Turks.

Their public debts.

'Trade.

Stores. purge themselves here with feare and trembling, more, peradventure, then in a battle. They punish most rigorously and capitally all treasons, revealers of secrets of State, defrauders of public moneys, but cannot proceed against a noble Venetian without interessing the whole council.

They have impenetrable wayes to discover secrets and offenders; they are masters of the denoncias against perjuries, invaders of the government, \&c. and their authority is very great, as it ought to bee, to prevent disorders and to punish great offenders.

The Quarantia criminale is a supreame council too, and consists of forty, and there are three counsellors preside there who represent the person of the Prince. They are most of them of the nobility of the second forme, to that end those of the first rank should not ingrosse all. They have place and vote in the senate. There are other two magistracies each consisting of 40. The former determineth appeales in things arising in the citty, as the second does in things arising on the terra ferma ; they succeed each other every 16 moneths, the second comeing into the place of the first, and the third of the second, soe that in time they all come into the Senate, and have knowledge of matters of weight. These are the chief magistracies, and are of greater authority in the republique.

I will now consider the present state of this Comonwealth in relation to her neighbours. Shee has lately made peace with the Turk, and most probable it is this peace may continue, at least soe long as the public one of Christendome does ; the Turk generally takeing advantage of our dissentions, to devoure us one after another. Besides, seing with what difficulty and expence of men and treasure hee has managed a warre against this state, it is not probable hee will attacque them yet awhile; the private divisions in his own family, and some discontents at home, induce mee to believe that monarch will breath awhile, before hee attempts anything against this state, whatever hee may doe against some other Christian princes.

The state of Venice dureing the 25 yeares warre has incurred great debts, haveing consumed on a strict account 180 millions of duckats. They have alsoe lost a great part of the trade they formerly had, and lastly exhausted their stores of warre. To recruite these is their present designe, which they hope to accomplish under the benefit of the present peace, and to that end they spread all their netts to discharge their debts. They reduce interest from 7 to 4 per cent. They goe on selling the remainders of Church lands assigned by the late Pope to bee employed in the warre. They retrench their militias by sea and land. They improve their revenue by exact menage, and they take the utmost advantages of 
confiscations. To encrease trade, they give all encouragement imaginable; the port being free, the Turks begin to come thither in some numbers, and the State treats them with all kindnesse; they are every day recruiting their arsenall with all necessaries, and they hold this as needfull as paying of their debts, or haveing money in their purses; and to this end they appropriate 250 thousand duckats per annum; which rightly applyed will goe a great way in it.

Their revenue is almost 4 millions of duckats per annum.

Their charge is about 3 millions and a halfe.

Revenue.

Charge.

Their militia by land in garrisons is 2000 foot, and about 1100 horse; by sea Militias by land. they maintayn 5 shipps, 24 galleys, and 4 galeasses; these are their constant Fleet by sea. guards upon establishment. In their fleet they expend 360,000 duckats annually, and in their land soldiers somewhat above half as much.

The Venetians are in their lives and conversation vitious enough, and not lesse In relation to carefull to preserve their spirituall then their civil liberties. Dureing the late warres, induced by necessity, and bribed by the Pope with the liberty of dissolving two orders and selling their lands, which amounted to 800 thousand dukats, they gave way with much unwillingnesse that the Jesuites might inhabite there, but in conversation they keepe at distance.

A breach between the Pope and them would ruine both, and involve all Italy To the Pope: in warre and destruction. It is certain that the Pope has pretention just enough, which yet he dares not set on foot. The Polisene di Rovigo is part of the Dutchy of Ferrara, which whole dutchy was bought by the apostolic see in the time of Clement 8 , to the infinite regret of the commonwealth ; but, for the reasons aforesaid, the Popes dare not attempt the recovery of it. This state seemes to stand Saroy. well enough with Savoy, nor does there appeare any probable cause of breach, unless it bee for the ayry title of King of Cypress to which both pretend; but they will doubtlesse joyne to preserve and mayntaine each other, wherein the public peace of Italy is concerned, and of which that Duke keepes a strong key.

This State keepes a good intelligence with the house of Medicis, which family, Florence. though raysed by the Austrians, yet finding itself surrounded by Spanish garrisons, and that the Kings of Spaine are powerfull enough in Italy to oppresse it, does maintayne a neutrality, seeming however more addicted to France than Spayne; but, however, this state is very confident that prince would never bee content to see the armes of France planted in Italy, and entertaines a strict intelligence with that family, as being well assured they will alwayes joyne hand with this republique for the keeping out of strangers and maintayning the public peace. 
Genoa.

Mantua.

Modena.

Parma.

That is would give license to sell wine, flesh, and bread in his howse, a considerable advantage in itself, but injurious to the State.
As to Genoa, all the world knowes the antient animosities and rancors that have been between this and that common wealth, which are not yet forgotten, at least by the Venetians; for even when the Venetians in the late warres were offered ayds and helpes from the Genoeses, provided their forces might goe jointly together, this state slighted and rejected the motion. There is noe apparent cause of any unkindnesse between these two henns of the game. Venice did one while consider Genoa with a jealous look whilst they were soe mightily ligued with the Spaniard, but now begins to have some esteeme of their policy and foresight, since they have found a way to maintaine a correspondance with France, by which meanes the navigation of Provence being open, the citty of Genoa is well supplyed with provisions, without being necessitated to expect them from Milan, Naples, and Sicily.

The state of Venice has alwayes endeavoured to maintayn a good intelligence with the Duke of Mantua, styling him her sonne; and indeed on all occasions testified a parental care of him ; frequently engageing herselfe in his quarels, the better to assure his dependance upon her, and secure Casal in Montserrat, which serves as a bulwark to all Italy on that part of it.

As to Modena, the state of Venice has alwayes endeavoured to maintaine a good correspondence with the Duke of Modena, but begun to look about her when she understood that Duke Francis was of an active, unquiet, ambitious temper, desirous of enlargeing his narrow bounds, particularly that he was intent upon the recovery of Ferrara, induced thereunto from an opinion hee had that the people of that province were weary of their new churchmen, and longed for their old masters. The said Duke went to Madrid to engage the king in his behalf, but received a denyall; from thence hee went to Paris, and received a ready promise, provided hee would first ayd them to conquer Milan. The French knew they had nothing in Italy to loose, soe that they run noe great hazard. The Pope was not uninformed of it, and the Venetians, to necessitate the said Duke to retire from such designes, were desirous the Pope should put a strong garrison into the place, and all this to preserve the peace of Italy, which alone renders her considerable in the eyes of the rest of the monarchs of Europe.

The republique of Venice does usually preserve a faire correspondence with the Duke of Parma, who reciprocally endeavours the same, and to that end entertayns always a resident in Venice; but soe it happened, some eight yeares since, that the said resident, pretending to keep a butchery and a buttery in his howse, the Senat sent to him to forbeare it, which hee not doing, they complained to the Duke, who recalled him indeed, but yet tooke the senat's complaint to heart, for 
hee presently gave sufficient evidencies of his dissatisfaction by sending all those that were condemned as slaves in his territories unto the state of Genoa, whom untill that time hee had constantly sent to Venice.

This State has not soe cordiall and sincere affection for any people as for the Suisses and Grisons, because, first, shee has noe jealousy of them, and secondly they, like herself, are chiefly intent upon preserving their liberty and freedom ; the maine end of all Republiques. This republique will certainly joyn with either of the two crownes against that which shall endeavor to usurpe the Grisons and the Valtoline; as shee did between France and Spayne, not out of love to the former but out of self-preservation, the state of Venice desiring to keepe things in Italy in the condition wherein they now are. True it is this State never makes use of these in any of her warres. The reason I conceive is, because they are her neighbours, and if any of such auxiliarys should play them a trick, there are more at hand to second them. But withall this State does indeare those of the Valtoline; does at her owne charge maintayn a certain number of young men of that province at their studies at Padoa at her own charge; and in Swisserland majntayns a constant resident.

The republique of Venice has great feare as well as jealousie of the howse of Austria ; first, because the territories of that family surround this State all on the coast of Germany; secondly, because they are powerfull in Italy, as well as ambitious; and lastly, because they know that they have usurped a great deale from that family, particularly of the patriarchshipp of Aquilea. When this monarch was rampant, and attempted an universall empire, this State did all they could to thwart them, as questionlesse they now would any other that should set up in the same way. They often invited the Turk to invade them; supported the defection of Bethlem Gabor; sided with the Prince Palatin; encouraged all the troubles in Germany ; ayded the Duke of Mantua with open and great force; and joyned with France to bring Gustarus Adolphus into Germany. They alsoe advised and counselled Queen Elizabeth to support the Hollanders. By all this it is easy to judge how they then stood affected; and judgeing by the same rule it is as easie to know how they now stand disposed. They only endeavor'd to impede the growing grandeur of the howse least it might have swallowed up their republique. Nor would they now see that monarchy ruined, apprehending the same consequence upon their own; they are very jealous also of their dominions in the Adriatick Gulf, in which they have noe other competitors then the subjects of that howse.

Besides all this, Brescia, Bergamo, and Crema are antient members of the voL. XXXVII.

As to the Grisons and Suisses.
As to the house of Austria and Spayne. 
Dutchy of Milan. By this your Majesty may see the Venetians thus farr have been jealous of the Spanyards, but now much more apprehend the French, as I shall evince.

As to France, the Venetians have had frequent experience of the sad consequences which befall them as often as they have France for their neighbours; and of their advantage when most remote from them; soe that they would have France guardant, not rampant; they would have them live but not devoure. Had not the warre of Candia taken up all their thoughts, eyes, and eares, for some yeares, this State would have been makeing parties against them; and now that they are free from troubles, assure yourself this State will run into any league to divert the progressions of that monarchy, which is already too formidable. Nor are those wanting who averr this warre of Candia to have been the product of Richelieu's brayns, to the end this State might bee taken up in the cares of preserving itselfe, and not hinder the proceeding of their neighbors. Withall, the mayn end of Besiers comeing hither was to draw this State into a league with that King, and on those termes he engaged to recover what was then lost in Candia. But this State, unwilling to depend on any party, excused itself in faire termes, and the King in a huff recalled his ambassador, who for haveing spoken somewhat too roughly in the college was not very wellcome to them, nor doe the Venetians stick to say that the French lost Candia by their base deserting it.

As to England, there has ever been a good intelligence between this State and England, possible in regard England is remoate from them; has noe pretentions to annoy them; and by trade affoards them many advantages. But more especially the Venetians court that kingdom as arbitrator of the affayres between the two pretending crowns, and considering it is the concerne of that monarch as of their own state to keepe the ballance even. Though there have not been many leagues between that crown and this State, yet their common interests have united them, soe that there has ever been a good correspondence, and never any breach between them, the Venetians still acting the same things in the east which the English doe in the west. As to Denmark, Swedeland, \&c., this State is little concerned with the first of the two crowns, nor much with the last; since the descent of Gustavus Adolphus into Germany, which this state did at that time encourage, for the reasons præalleadged, ayding him then with great sums of moneys. As to the Hollanders, when the Hollanders first revolted, the Venetians encouraged England and France to ayd them; and they themselves contributed large sums to their support; nor were the Dutch ingratefull for it, seing they sent to the Signorie upon that occasion of the excomunication of Paul the 5th to offer 
them whatsoever moneys or men they desired, as England alsoe did; moreover in the warre of Gradisca the Hollanders did send 600 foot payd by themselves to serve the Venetians against the emperor; but when in processe of time this republique perceived that the French seconded by the Hollanders went on victoriously in every place, and that the Spanyard could not hold up the buckler against them, she began to withdraw her hand, it not being her designe to ruine, but only to humble, the Spanyard. The Dutch to this day pretend an arrear of six millions of florins due to them from this State, on accompt of that league, which the Venetians at length deserted. The Commonwealth at this time hath a good correspondence with the states of Holland; their interests of peace, trade, and obstructing the overgrowing greatnesse of any monarch, being the same.

As to Poland, this State maintaynes a good intelligence with Poland, as being a mayn buckler rgainst the Turk; shee still endeavors to keepe all quiet in and about that kingdome, and is herself grieved when they suffer, either from without or within, as was manifest in the late warres, where the Cossacks, who used to infest the Black Sea, and forced the Grand Signor to divide his fleets, did then, by reason of their owne private dissentions, become a prey to the Turks, and unwillingly help to fill his gallies against the Venetians.

As to the Turk, certain it is this State would alwayes maintayn peace with this monarch ; trade, not warre, encrease of wealth, not enlargement of empire, being the object of this government. They only seated themselves here for peace and commerce; their lawes, their affections, their vertues and their vices dispose them altogether to these things; but whatever state lyes neare the Turkish moon must suffer eclipses; they have already robbed this State of three crownes, viz. Morea (formerly Thessaly), Cypress, and Candia. I should feare Zant and Cephalonia would follow, but I think not yet, that monarchy having seen with what difficulty hee has wrested the last from this State; but I cannot think they will long remaine secure, the animosities between them and us, through difference of religion, lawes, habits, languages, and in a word of all things that serve as a common ciment or ligament, give mee reason to doubt, as I say, that the Turk will not long leave these places inattempted; but that hee will not yet attempt them, I suppose may bee reasonably concluded from the general peace of all Christendome. The knowledge that monarch has of the resistance this State can make in case of a rupture, the private divisions in his howse and family, and possibly other necessities that government may have at present, that doe not yet fall under my observation.

This is certain, the republique applyes herself sedulously to maintayn this peace 2 в 2 
and to endeare it by Commerce, which begins to flourish apace between this signorie and that large monarch. Besides, the State keepes an ambassador constantly there at a great expence, whose mayn business is to purchase the affections of the great men at court, and sometimes too of the Sultanes by force of money and the like.

I forbeare to say anything of the scituation of this place, when and on what occasion it was founded. These things are to bee found in many who have particularly treated on them, such as Cardinal Contareno, Bernardo, Giustiniao, Munster, Bardi, Sansovini, and many others.

Thus much only I thought was fit to be presented to your Majesty's view by,

Sire,

\section{Your Majesty's}

Most loyal and obedient subiect, Fatconberg. 